\title{
Application of hydrogen optical storage cogeneration in ships
}

\author{
Zheng Fang ${ }^{1, a^{*}}$, Zhuoer Wang ${ }^{2, b}$, Lan Wei ${ }^{3, c}$, Zhengkang Zhou ${ }^{4, \mathrm{~d}}$ \\ ${ }^{1}$ School of Navigation, Wuhan University of Technology, Wuhan, China \\ ${ }^{2}$ School of Information Engineering, Wuhan University of Technology, Wuhan, China \\ ${ }^{3}$ School of Information Engineering, Wuhan University of Technology, Wuhan, China \\ ${ }^{4}$ School of Information Engineering, Wuhan University of Technology, Wuhan, China
}

\begin{abstract}
This project aims at the problems of low efficiency and large emission of LNG energy and other fossil energy. Combined with existing basic hydrogen fuel cell technology and solar power generation technology, a set of ship power management system based on hydrogen fuel cell is designed. Combined with solar energy technology, it effectively improves fuel efficiency and greatly reduces greenhouse gas emissions.
\end{abstract}

\section{INTRODUCTION}

Based on the current research results and development status of hydrogen fuel cell and solar energy technology at home and abroad, this project proposes a ship power management system with hydrogen fuel cell and solar energy as the main energy, to realize a stable, safe, efficient and energy-saving ship power system with clean energy and less emissions, which provides a new scheme for the ship power system.

In this paper, based on the development of hydrogen fuel cell and solar technology at home and abroad, as well as the existing application situation, joint power light for hydrogen storage application in the ship.

\section{Research Content}

\subsection{Principle and application of hydrogen fuel cell}

Fuel cell (FC) is a kind of isothermal, directly stored in the fuel and oxidant chemical energy into electricity efficiently, pollution-free power generation device. Its power generation principle is the same as the chemical power source. The electrode provides a place for electron transfer. The anode catalyzes the oxidation process of fuel such as hydrogen, and the cathode catalyzes the reduction process of oxidizer such as oxygen. Conducting ions migrate within the electrolyte that separates the anode from the cathode, and electrons do work through external circuits that form electrical circuits. But the working mode of $\mathrm{FC}$ is different from conventional chemical power sources, and more similar to gasoline and diesel generators. Its fuel and oxidant are stored not in the battery, but in a tank outside the battery. When the battery is generating electricity, fuel and oxidant should be continuously fed into the battery, the reaction products should be discharged, and a certain amount of waste heat should be eliminated to maintain the constant working temperature of the battery. FC itself only determines the power output, and its energy storage is determined by the amount of fuel and oxidant stored in the tank

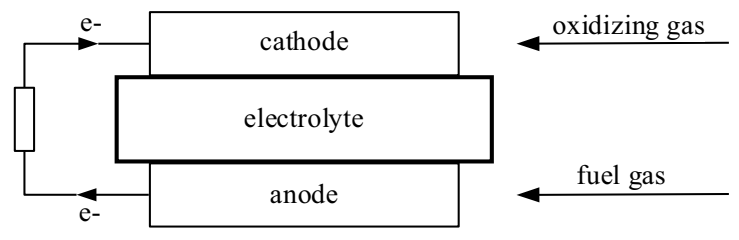

Figure 1. The structure and operation schematic diagram of a single cell for hydrogen and oxygen fuel cells.

In the anode, hydrogen and the $\mathrm{OH}^{-}$of alkali under the action of an electrocatalyst, oxidation reaction occurs to generate water and electrons:

$$
\mathrm{H}_{2}+2 \mathrm{OH}^{-} \rightarrow \mathrm{H}_{2} \mathrm{O}+2 e^{-} \quad \varphi^{0}=-0.828 \mathrm{~V}
$$

Electrons reach the cathode through the external circuit, and participate in the reduction reaction of oxygen under the action of cathode electrocatalyst:

$$
\frac{1}{2} \mathrm{O}_{2}+\mathrm{H}_{2} \mathrm{O}+2 e^{-} \rightarrow 2 \mathrm{OH}^{-} \quad \varphi^{0}=0.401 \mathrm{~V}
$$

The resulting $\mathrm{OH}^{-}$migrates to the hydrogen electrode. In order to keep the battery working continuously, in addition to supplying hydrogen and oxygen at the same speed as the hydrogen and oxygen consumed by the battery, the water generated by the battery reaction needs to be discharged continuously and at the same speed from

\footnotetext{
"Zheng Fang: a2779522976@qq.com

b288484@whut.edu.cn

c288489@whut.edu.cn

d288649@whut.edu.cn
} 
the anode (hydrogen electrode) to maintain the constant electrolyte concentration; Eliminate the waste heat from the battery reaction to maintain the constant operating temperature of the battery.

\subsection{Photovoltaic cell principle and application}

Solar refers to the projected onto the solar radiant energy on the ground, generalized solar include such as hydropower, wind energy, ocean energy, tidal power indirect solar energy resources, everything in our life cannot leave the solar energy, solar energy is everywhere, this section to tell the ship power used in the field of solar energy is in a narrow sense, namely the sun radiation energy. The solar radiant energy projected by the sun onto the earth's surface every year is huge, equivalent to about $13 \times 1013$ tons of standard coal energy. The radiant energy of the sun will be projected to every part of the earth, and it is very convenient to exploit and use. The key is that the use of solar energy will not cause environmental pollution, and the supply of inexhaustible, with good sustainability. There are many ways to use solar energy, such as the conversion of light energy to heat energy, electricity, hydrogen energy, biomass energy and so on. The main way to use solar energy on ships today is to convert solar energy into electric energy for use, namely photovoltaic power generation.

Photovoltaic power generation is based on the principle of photovolt effect, using solar cells to convert solar light energy directly into electric energy. Whether used independently or connected to the grid, the photovoltaic power generation system is mainly composed of three parts: solar panels (modules), controllers and inverters, as shown in Figure 2. When too much light shines on the semiconductor surface, some of the valence electrons in the semiconductor are impacted by solar photons, thus breaking free from the covalent bonds, thus forming many non-equilibrium electron-hole pairs. Under the P-N junction, these electrons flow, and if a load is applied to both ends of the semiconductor, a current will flow through the load. Many small solar photovoltaic cells, connected in series or parallel to form photovoltaic modules, can convert solar energy into electricity large enough.

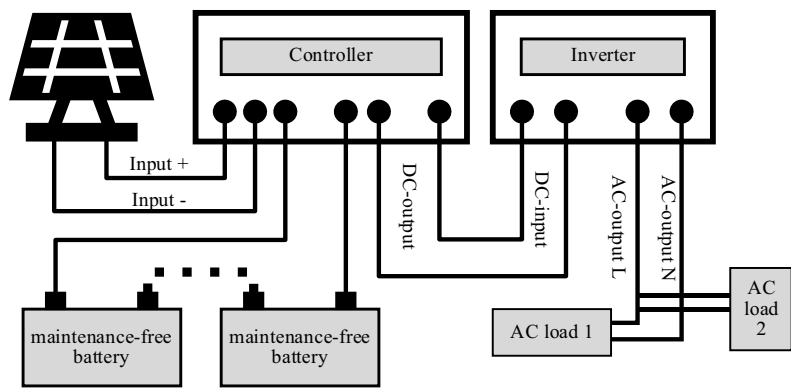

Figure 2. photovoltaic power generation systems

Hydrogen optical storage combined power generation system

Joint system includes a fuel cell, photovoltaic cells and batteries, photovoltaic system for fuel cell and the output of DC voltage conversion is available to load voltage level, need to join the power converter, this system is equipped with DC load and AC load interface, so the power converter for DC/DC converter and DC/AC converter.

The system block diagram is shown in Figure 3.

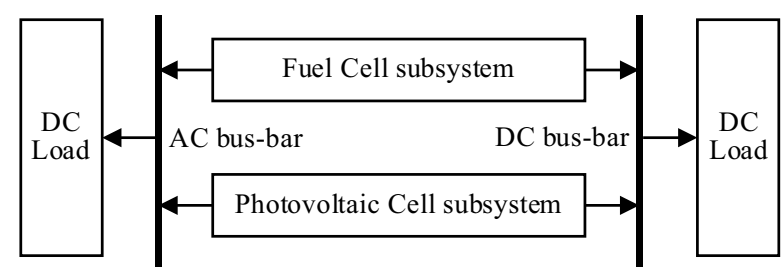

Figure 3. hydrogen power generation system of optical storage system block diagram

The design of the co-generation system architecture is to integrate the fuel cell power generation subsystem and the photovoltaic cell power generation subsystem. Considering the DC load in the system, the system adopts the DC bus structure. In the fuel cell power generation system architecture, the output end of $\mathrm{DC} / \mathrm{DC} 1$ is selected as the DC bus. The battery is directly connected in parallel on the bus, and the photovoltaic cell is connected in parallel on the bus through DC/DC2. Due to fuel cell power generation cost is higher than the current power grid electricity price, to improve efficiency of power generation system, this system is designed for backup UPS system, normal power grid, the switch is connected to the node, the load directly by the grid power supply, DC/DC2 and DC/AC working in the idle state, photovoltaic battery to charge battery, fuel cell does not work. When the power down signal of the grid is detected, the switch is connected to node 2 and the DC/AC output energy. According to the energy management strategy, the power flow between the fuel cell, photovoltaic cell, load and battery is coordinated and controlled to provide continuous and stable energy supply for DC load and AC load. The integrated system structure is shown in the figure below:

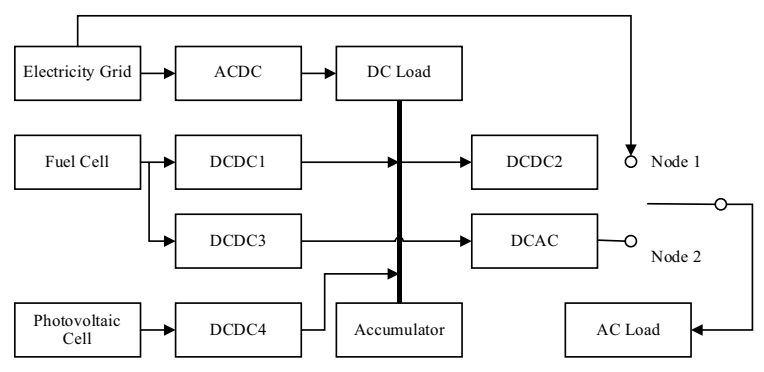

Figure 4. combined power generation system structure

The co-generation system is uniformly scheduled by the central monitoring unit. Each module of the cogeneration system is connected with the central monitoring unit through the communication interface to receive the given value at the current time and give feedback to the actual value. The central monitoring unit collects the power demands of DC load and AC load, and dispatches the power according to the current state of the 
power output module according to the corresponding energy management strategy.

\section{FEASIBILITy ANALysis}

\subsection{Target analysis of coordinated control of hydrogen optical storage co-generation system}

The design of hydrogen optical storage co-generation system should not only ensure the dynamic balance of power and current in the system, but also ensure the stable output of the system when the load changes, and fully consider the operating cost and service life of the system to ensure the safe, stable and continuous work of the system.

From the perspective of system power and current balance, the system should meet the following requirements:

$$
\begin{array}{r}
P_{P V}+P_{F C}=P_{B A T}+P_{D C}+P_{A C} \\
i_{D C / D C 4}+i_{D C / D C 1}=i_{B A T}+i_{D C}+i_{D C / D C 2} \\
i_{A C}=i_{D C / D C 2}+i_{D C / D C 3} \\
i_{F C}=i_{D C / D C 1}+i_{D C / D C 3}
\end{array}
$$

When the load power changes, it is necessary to change the supply energy to maintain the balance between supply and demand of the system power. Because there is a mechanical link in the fuel cell output regulation and the inertia time is long, the output power of photovoltaic cells and batteries should be adjusted as much as possible to respond to the change of load. For photovoltaic cells, fuel cells and batteries, their output characteristics have their own range, so the control system needs to limit their voltage, current and power within the normal operating range. When the maximum power output of the system is still unable to meet the power demand, necessary measures should be taken to make the supply and demand balance again.

From the perspective of power generation cost, the energy generated by photovoltaic cells is preferred because there is no extra cost after photovoltaic cells are connected. The cost of power generation of fuel cells is higher than that of energy obtained from the grid, and the design margin of grid side energy supply capacity is sufficient. Therefore, fuel cells are generally applied in the case of power failure of the grid. Under normal circumstances, the system is powered by photovoltaic and power grid.

From the point of view of system life, the service life of the system is often subject to the service life of the battery. Overcharge and overdischarge of the battery will reduce the service life of the battery, so it is necessary to avoid the overcharge and overdischarge of the battery through reasonable control. For the fuel cell, its startup process is slow, and frequent start and stop will cause wear and tear on the mechanical links, so it is necessary to reduce the start and stop times of the fuel cell in the system operation. The output of the fuel cell by power converter connected to the load, when the fault the power converter, fuel cell to produce the large current is not consumption, also can affect the life of the fuel cell, in order to decrease the failure rate of the power converter, the control system design, the need to strictly control the power converter work within the scope of the set of voltage and current.

\subsection{Development status of hydrogen fuel cells and photovoltaic cells}

Marine hydrogen fuel cell technology is becoming mature. The 712th Research Institute of China Shipbuilding Industry Corporation (CSIC) has mastered the engineering core technology of fuel cell engine for $30 \mathrm{~kW}$ logistics vehicles by undertaking the key project of "Research and Development of Fast Dynamic Response Fuel Cell Engine" for new energy vehicles of the Ministry of Science and Technology.

Domestic Marine hydrogen fuel cell propulsion engineering research work mainly focused on DiQiYiEr institute of China shipbuilding industry group, through undertaking, national government projects in the field of Marine and underwater equipments of hydrogen fuel cell power system technology development of research work has accumulated rich experience, the hydrogen fuel battery pile, hydrogen source technology, control and energy management, system integration and so on key technology breakthrough, in the field of Marine hydrogen fuel cell propulsion technology in the domestic leading position, have a good base for technical reserves.

The state has issued relevant policies to support it. According to the State Council in May 2015 the deployment of the all-round implementation of the strategy of manufacturing power file "made in China 2025" high technology of ship shipbuilding industry in 2025 manufacturing power requirements, around the hydrogen fuel cell propulsion technology in energy saving, environmental protection, safe and efficient market demand and development trend in the field of ship propulsion system, to break through with independent intellectual property rights of Marine hydrogen fuel cell propulsion engineering into the goal, through policy guidance, the key technology research and technology application of green environmental protection, realize the Marine autonomization and hydrogen fuel cell propulsion system engineering, accelerate the transformation and upgrading of shipbuilding industry, In order to meet the market demand of high performance green ships in the field of inland river, offshore and ocean-going ships.

At present, the application of solar energy in the field of ship power mainly includes the following aspects:

1. Convert solar energy into electricity as the main power source of the ship, that is, the energy of the main engine of the ship basically comes from the electricity generated by solar energy. Such a solar ship must adjust the main engine power configuration to the appropriate size according to the ship's size, speed, mission requirements, etc., which is a big design challenge.

2. The solar energy as the ship's auxiliary mechanical power energy of large ship auxiliary machine has a lot of, in order to facilitate control, tend to have independent 
power systems or to control the ship power station, at this time, you can use electricity produced by solar energy as the equipment of power energy, have the effect of energy conservation and emissions reduction, and the large ships deck has enough place to put solar panels.

3.The solar lighting system as Marine refrigeration and air conditioning equipment and life energy oceangoing ships sailing schedule relatively long commonly, air conditioning refrigeration system and lighting system such as the energy demand in life if all rely on diesel power generation to provide power, so here the fuel cost is a lot of money, but also has the pollution to the environment. However, solar energy can be used to solve these problems perfectly, such as solar water heaters.

4.Solar energy as a large oil tanker unloading and heating system energy large oil tanker general sailing time is long, high fire prevention requirements, winter oil unloading is difficult, and these just for the solar energy application in ship is good enough to play a space, can be in a tanker enough solar panels and batteries, can saving a lot of solar energy, can through the solar energy water heater to heat preservation of oil, discharge time and energy can be used as a lighter goods equipment

\section{Innovation Points And Project FEATURES}

Solar energy is the most abundant renewable energy source on earth, and photovoltaic cells are commonly used to convert solar energy into electricity. Photovoltaic cells do not need to provide fuel supply in the process of conversion, and do not emit any pollutants, with good environmental protection and economy.

Hydrogen energy as a new renewable energy has many advantages: abundant hydrogen reserves; High energy density of hydrogen; Hydrogen is clean and pollution-free. With the development of hydrogen production and storage technology, the utilization of hydrogen energy will be more and more extensive. Fuel cell is a commonly used electrochemical power generation device to complete the conversion of hydrogen energy to electric energy. Fuel cell power generation does not go through the thermal process and is not restricted by the Carnot cycle, so the energy conversion efficiency is high.

The output characteristics of fuel cell and photovoltaic cell are very complementary. The output of fuel cell is stable but the dynamic response is slow, while the dynamic response of photovoltaic cell is fast but the output is greatly affected by weather. Therefore, it is considered to establish a joint power generation system, which integrates the advantages of the two kinds of energy to provide continuous and stable power supply for the load. This kind of cogeneration system is of great significance to solve the energy shortage and reduce the pressure of environmental pollution.

\section{ACKNOWLEDGEMENT}

This work was supported by National university student social practice and science contest on energy saving \& emission reduction 414-3120600201.

\section{REFERENCES}

1. Huang Lian. Application and prospect of solar energy in Marine power field $[\mathrm{J}]$. Science, Technology Innovation and Application,2020(03):183-184.

2. Fu Tiantian. Review of Development of Hydrogen Fuel Cell for Electric Vehicle [J]. Chinese Journal of Power Sources,2017,41(04):651-653.

3. Wang Jiaheng, Han Zhen. Development Status and Trend of Hydrogen Fuel Cell Technology in China [J]. Automobile Practical Technology,2019(22):2023.

4. Shen Wei. Marine propulsion system revolution is the inevitable choice for carbon emission reduction [J]. China Shipping Survey,2021(01):69-72.

5. Yang Qingyong. Application Analysis of Hydrogen Fuel on Ships [J]. Journal of Qingdao Ocean Seafarers Vocational College,2020,41(04): 41-44+59.

6. Ma Yukun, Zhang Qinjie, Zhao Junjie. Marine Materials \& Market,2019(03):14-16.

7. Peng Yuanting, $\mathrm{Xu}$ Zengshi. Research on Marine Hydrogen Fuel Cell Propulsion Technology [J]. Engineering Sciences,2019,21(06):18-21.

8. Feng Juan. Research on Performance Optimization of Marine Hydrogen Fuel Cell [D]. Jiangsu University of Science and Technology,2018.

9. Yu Quan-hu. Advances in Hydrogen Energy and Fuel Cells and Their Applications in Ships [J]. Ships,2020,31(05):69-76. 